\title{
AN EXPLORATORY STUDY ON FACTORS INFLUENCING MAJOR SELECTION
}

\author{
Juyun Cho, Colorado State University-Pueblo, joey.cho@colostate-pueblo.edu \\ Susan Jones, Utah State University, susan.jones@usu.edu \\ David Olsen, Utah State University, david.olsen@usu.edu
}

\begin{abstract}
Despite the increased use of innovative computerrelated technologies, undergraduate students seem less interested in the technology-related majors, resulting in declining Information Systems (IS) program enrollments. With these existing challenges, IS educators and administrators must understand the factors affecting college major choice. Through extensive literature reviews, we collected important influencing factors and utilized these factors in our survey. This study provides insight into the identification of critical factors that may revitalize declining IS enrollments. The survey conducted as part of this research addresses condition, background, outcome, and interest factors relating to major choice. After the analysis of our survey data, the response differences between high school and college students and between male and female students are reported.
\end{abstract}

Keywords: IS Enrollment, Student Perception, Student Interest, Critical Factor, College Major Selection.

\section{INTRODUCTION}

Information systems (IS) and information technologies (IT) have provided a strong, innovative framework by which organizations have capitalized on their competitive advantage. Information systems have allowed efficient dissemination and cultivation of information, providing overall value to the organization [15]. Although organizations have been enjoying beneficial rewards for implementing information technologies, creating many new IS jobs, and offering strong IS starting salaries; IS-based academic departments and programs are not enjoying the same competitive advantage in their recruitment of students [6]. Literature dating back to the late 1980s identified declining enrollment trends in computer-related majors, forecasting the impact currently experienced in many academic institutions as well as the shortages of college-trained IS professionals [2].

Demand for IS professionals in the United States continues to rise regardless of the challenges facing the industry; i.e., offshore outsourcing, immigration, and economic fluctuations [12]. According to Bureau of Labor Statistics data, IS employment in the United States reached a record high of 3.472 million workers, ending March 31, 2007. This high surpasses the previous record set at the height of the dot-com employment boom, September 30, 2001 [3]. Additional information from the Bureau of Labor Statistics indicates the demand for computer and information systems managers, computer systems analysts, computer scientists, and database administrators is expected to "grow faster than the average" through the year 2014, and computer security workers are projected to observe a "rapid job growth." The only upper-level computing field expecting a slower growth pattern is computer programming [14].

There is an abundance of applicable research addressing the declining IS interest issues; discussions generated from prior IS enrollment research cover a broad range of factors - poor job perception beliefs to inadequate high school course offerings. The studies, however, have not attempted to compare the important factors influencing a college major selection to the perceived importance of the same factors. Thus, the research questions that guided the study follow:

1) What condition, background, outcome, and interest factors are related to choice of major?

2) What condition, background, outcome, and interest factors are perceived of the IS major?

3) Does the level of importance assigned to college major selection factors differ between high school and college students?

4) Does the level of importance assigned to college major selection factors differ between male and female students?

Realizing that a capital/physical-based focus does not differentiate organizations as it has in the past, organizations create advantages through intellectual capital [9]. The research results of this study generate information that academic administrators can use as valuable organizational knowledge, aiding in the IS enrollment problem-solving process. The goal of this study is to comprehensively look at the related 
literature and selectively examine the leading factors influencing the selection of a college major. The literature review also aided the creation of the survey that was administered to undergraduate students (oncampus and concurrent enrollment status) at a statelevel university. The students were enrolled in introductory Management Information Systems (MIS) courses.

This study does not attempt to address the issues and implications pertaining to IS workforce shortages or economic factors, curriculum design issues, or programs other than undergraduate programs.

\section{LITERATURE REVIEW}

Our literature review suggests that academic administrators at colleges and universities around the United States are under pressure to increase enrollment in IS-related majors. Several studies examining college major selection covered a wide array of factors, some include: high school experience factors [13]; job-, image-, and cost-related beliefs [17, 1]; turning-point patterns [8]; students' perceptions of the IS major; and the financial market surge [2].

Additional research presents hypotheses, explanations, and speculations as to the origin of the IS-enrollment declines. A 2005 targeted study conducted by Lomerson and Pollacia indicates a lack of available, accurate career and college information to high school students [11]. Another study points to a mismatch between the skills industries require and the skills attained in college-level academic programs [16].

Lenox et al. conducted a survey of academic institutions offering computer science (CS), information systems (IS), and/or information technology (IT) programs; 91.5 percent of the respondents confirmed decreases in undergraduate enrollment. The top six findings reported for the enrollment decline were: "outsourcing of CS/IS/IT jobs (67\%), the economy in general (59.8\%), the dot.com failure $(48.8 \%)$, the cyclic nature of business (40\%), decline in students' analytic abilities (29.26\%) and failure of the institution to actively recruit students (26.8\%).” [10]

Hoganson was among the researchers who suggest that computer-degree program administrators may mitigate some of the impact of outsourcing on job prospects and program enrollment by developing curriculum around a critical and strategic framework. As noted in the earlier cited labor statistics, programming jobs can be easily outsourced; however, jobs such as entrepreneur, product designer, research engineer, system analyst, computer science researcher, requirements analyst, system architect, and system designer are more difficult to outsource [8].

Moreover, a study worth mentioning noted that enrollment decreases can be directly related to deficiencies in program curriculum and in program administration. The two more notable deficiencies were a shortage of training in entrepreneurship and poor marketing efforts [5].

In response to similar studies and reports, organizations such as Americas' Conference on Information Systems (AMCIS), Computer Science Teachers Association (CSTA), and Association for Computing Machinery (ACM) are mounting marketing initiatives to reverse the students' narrow perceptions of computing. In fact, the CSTA is actively involved in curriculum-related issues in America's high schools, and ACM plans an extensive marketing campaign to provide greater visibility for ACM events. These organizational efforts are designed to increase awareness of the health of computing and call attention to the optimistic projections for computing careers [4].

\section{RESEARCH METHODOLOGY}

Survey questions were developed during an extensive literature review, and a pilot test was conducted to assess the clarity of questions, adequacy of instructions, effectiveness of data capture system, and respondents' understanding of the meaning of questions. The survey questions, modified based on the pilot test responses, were converted to a webbased survey system through HTML and PHP code. The PHP code was developed to dump survey data on the web into a MySQL database, running under a Linux operating system. The collected data were exported into a tab-delimited file and imported into Microsoft Excel. Finally, the Excel file was imported into a SPSS statistical package for further analysis.

The data utilized in this study were gathered over a period of time between 2006 and 2007, through an 18-question online survey instrument. The research subjects were students who enrolled in on-campus and high school concurrent enrollment college introductory management information systems (MIS) courses at a large state university in a northwestern U.S. state. The MIS courses are designed to present an overview of information systems and its respective role in the organizational environment. 
In addition to the questions involving demographic variables, respondents were asked to specify the level of importance of factors believed to influence their choice of college major as well as their perceptions of the IS major. The scale consisted of five categories; extremely important (1), very important (2), important (3), somewhat important (4), and not at all important (5). Participation was voluntarily.

\section{ANALYSIS/DISCUSSION}

The group statistics focus on two major areas factors influencing students' choice of major and students' perceptions of IS major. We will discuss the factors exhibiting appropriate significance. Statistical significance at the 0.05 level was determined.

A total of 445 online responses were received. Sixteen of the responses were deemed invalid, leaving 429 (96\%) student surveys. The demographic information of participants follows:

1. 80 percent (343 students) of the respondents were college students. See Figure 1.

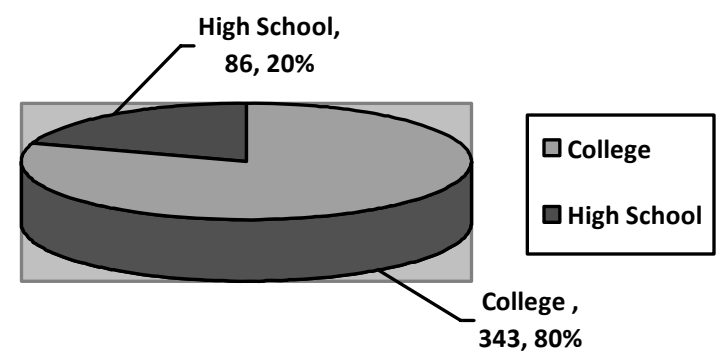

Figure 1. College and High School Distribution

2. 63.4 percent (272 students) of the respondents declared majors within the College of Business. See Figure 2.

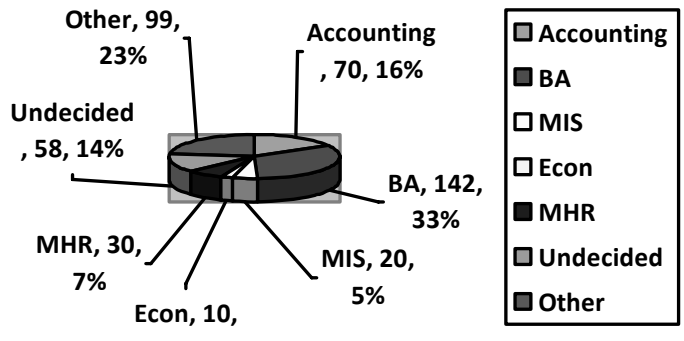

$2 \%$

Figure 2. College Major (BA: Business Administration, MIS: Management Information Systems, Econ: Economics, MHR: Management of Human Resources)
3. 85.3 percent (366 students) of the respondents reported Junior-class status or lower. See Figure 3.

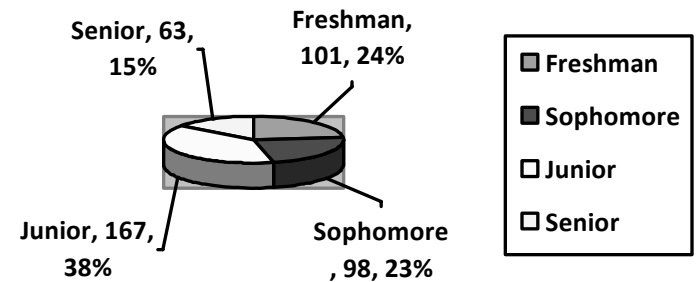

Figure 3. Student Rank Status

4. 62.5 percent (268 students) of the respondents were male. See Figure 4.

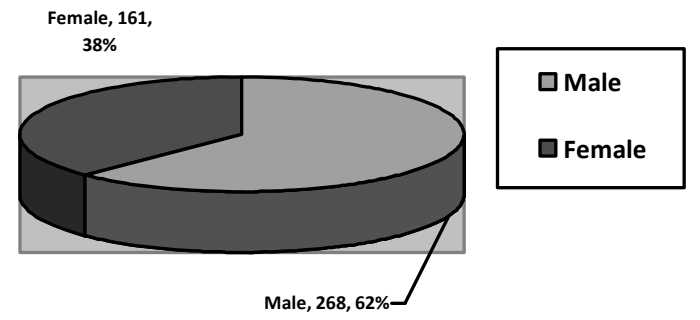

Figure 4. Gender Demographic

5. 90.9 percent (390 students) of the respondents identified race as "White or Caucasian." See Figure 5.

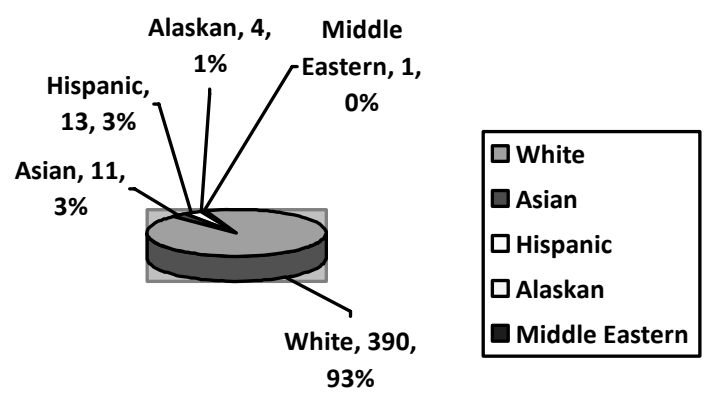

Figure 5. Race Demographic

6. Age range is $16-56$; 92.8 percent (398 students) are below the age 26; the average age is 21.64 with a standard deviation of 4.720. See Figure 6 . 


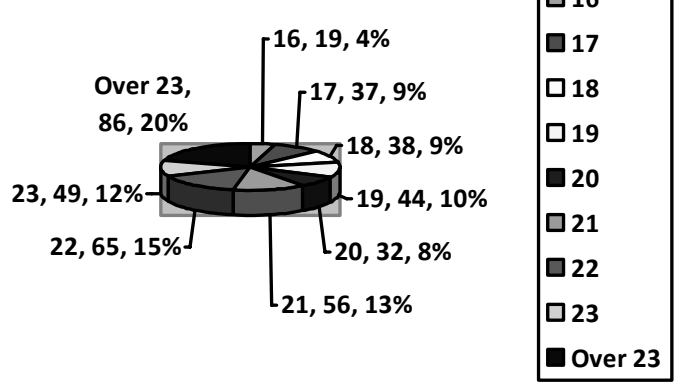

Figure 6. Age Distribution

\section{Factors Influencing Students' Choice of Major}

The survey (developed through an extensive literature review) identified important influencing factors in selecting a college major, and the respondents were asked to assign importance to the factors. The 12 selected factors were job market growth, job market stability, short-term earning potential, long-term earning potential, professional image of profession, social image of profession, amount of course work required/expected ease of earning the degree, aptitude in the subject, genuine interest in the subject, ability to maintain a high grade point average (GPA), intellectual challenge of the subject, and use of innovative technology (See Table $1)$.

\begin{tabular}{|l|l|}
\hline$\#$ & Factors \\
\hline 1 & Job market growth \\
\hline 2 & Job market stability \\
\hline 3 & Short-term earning potential \\
\hline 4 & Long-term earning potential \\
\hline 5 & Professional image of profession \\
\hline 6 & Social image of profession \\
\hline 7 & $\begin{array}{l}\text { Amount of course work required/expected ease } \\
\text { of earning the degree }\end{array}$ \\
\hline 8 & Aptitude in the subject \\
\hline 9 & Genuine interest in the subject \\
\hline 10 & $\begin{array}{l}\text { Ability to maintain a high grade point average } \\
\text { (GPA) }\end{array}$ \\
\hline 11 & Intellectual challenge of the subject \\
\hline 12 & Use of innovative technology \\
\hline
\end{tabular}

Table 1. Factors Used in the Survey

Table 2 shows the results of the independent t-test between college-aged respondents and high schoolage respondents. Three factors - amount of course work (.000), the genuine interest in subject (.015), and ability to maintain a high GPA (.000) - showed statistically significant differences $(\mathrm{p}<.05$ level $)$ between the two groups. Noticing the significance of
Lavene's Test for interest (.004) and GPA (.003) was less than .05, we used the "Equal Variances Not Assumed" test values (also represented in the table) for these three factors.

\begin{tabular}{|l|l|l|l|}
\hline \multirow{2}{*}{ Factors } & \multicolumn{2}{|l|}{$\begin{array}{l}\text { Lavene's Test } \\
\text { for Equality of } \\
\text { Variances }\end{array}$} & $\begin{array}{l}\text { t-test for } \\
\text { equality of } \\
\text { means }\end{array}$ \\
\cline { 2 - 4 } & $\mathrm{F}$ & Sig. & Sig.(2-tailed) \\
\hline $\begin{array}{l}\text { Amt of course } \\
\text { Equal variance } \\
\text { Not equal variance }\end{array}$ & 1.370 & .242 & \\
\hline $\begin{array}{l}\text { Interest } \\
\text { Equal variance } \\
\text { Not equal variance }\end{array}$ & 8.260 & .004 & .000 \\
\hline $\begin{array}{l}\text { GPA } \\
\text { Equal variance } \\
\text { Not equal variance }\end{array}$ & 8.888 & .000 \\
\hline
\end{tabular}

Table 2. Independent t-test Results

Further mean value analysis on the three factors reveals that high school students consider these three factors more important in selecting their majors than did the college students. Also important to note, the genuine interest in the subject, long-term earning potential, and job market stability (in order) were the three variables perceived as the most important by both groups. Table 3 explains the mean value differences with standard deviation.

\begin{tabular}{|c|c|c|c|}
\hline Factors & Level & Mean & $\begin{array}{l}\text { Std. } \\
\text { Deviation }\end{array}$ \\
\hline \multirow[t]{2}{*}{ Job growth } & College & 2.13 & 878 \\
\hline & High school & 2.33 & .860 \\
\hline \multirow[t]{2}{*}{ Job stability } & College & 1.86 & .821 \\
\hline & High school & 1.88 & .860 \\
\hline \multirow{2}{*}{$\begin{array}{l}\text { Short-term } \\
\text { earning }\end{array}$} & College & 2.88 & 1.002 \\
\hline & High school & 2.86 & .960 \\
\hline \multirow{2}{*}{$\begin{array}{l}\text { Long-term } \\
\text { earning }\end{array}$} & College & 1.68 & .833 \\
\hline & High school & 1.76 & .853 \\
\hline \multirow{2}{*}{$\begin{array}{l}\text { Professional } \\
\text { image }\end{array}$} & College & 2.51 & 1.076 \\
\hline & High school & 2.49 & 1.071 \\
\hline \multirow{2}{*}{$\begin{array}{l}\text { Social } \\
\text { image }\end{array}$} & College & 2.87 & 1.148 \\
\hline & High school & 2.78 & 1.152 \\
\hline \multirow{2}{*}{$\begin{array}{l}\text { Amt of } \\
\text { course }\end{array}$} & College & 3.13 & 1.116 \\
\hline & High school & 2.50 & .955 \\
\hline \multirow[t]{2}{*}{ Aptitude } & College & 2.15 & .843 \\
\hline & High school & 2.06 & .845 \\
\hline \multirow[t]{2}{*}{ Interest } & College & 1.57 & .780 \\
\hline & High school & 1.37 & .614 \\
\hline \multirow[t]{2}{*}{ GPA } & College & 2.55 & 1.013 \\
\hline & High school & 2.06 & .873 \\
\hline \multirow{2}{*}{$\begin{array}{l}\text { Intellectual } \\
\text { challenge }\end{array}$} & College & 2.59 & 1.101 \\
\hline & High school & 2.52 & 1.049 \\
\hline
\end{tabular}




\begin{tabular}{|l|l|l|l|}
\hline \multirow{2}{*}{ Technology } & College & 2.66 & .870 \\
\cline { 2 - 4 } & High school & 2.55 & 1.014 \\
\hline
\end{tabular}

Table 3. Group Statistics

(Smaller numbers represent more importance)

Even more interesting are the differences in the male and female responses. The independent t-test between these two groups illustrates that there is a statistically significant differences $(\mathrm{p}<.05$ level $)$ in long-term earning potential (.038), social image of profession (.040), amount of course work (.020), aptitude in the subject (.004), genuine interest in the subject (.000), GPA (.001), and intellectual challenge of the subject .001). We notice that the significance of Lavene's Test for long-term earning potential (.024), social image (.016), aptitude (.026), and interest (.000) is less than .05, so we use the "Equal Variances Not Assumed" test values for these factors (See Table 4).

\begin{tabular}{|l|l|l|l|}
\hline \multirow{2}{*}{ Factors } & \multicolumn{2}{|l|}{$\begin{array}{l}\text { Lavene's Test } \\
\text { for Equality of } \\
\text { Variances }\end{array}$} & $\begin{array}{l}\text { t-test for } \\
\text { equality of } \\
\text { means }\end{array}$ \\
\cline { 2 - 4 } & F & Sig. & Sig.(2-tailed) \\
\hline $\begin{array}{l}\text { Long-term } \\
\text { earning }\end{array}$ & 5.131 & .024 & \\
$\begin{array}{l}\text { Equal variance } \\
\text { Not equal variance }\end{array}$ & & & .027 \\
\hline $\begin{array}{l}\text { Social image } \\
\text { Equal variance } \\
\text { Not equal variance }\end{array}$ & 5.870 & .016 & .038 \\
\hline $\begin{array}{l}\text { Amt of course } \\
\text { Equal variance } \\
\text { Not equal variance }\end{array}$ & 2.624 & .106 & .034 \\
\hline $\begin{array}{l}\text { Aptitude } \\
\text { Equal variance } \\
\text { Not equal variance }\end{array}$ & 4.962 & .026 & .040 \\
\hline $\begin{array}{l}\text { Interest } \\
\text { Equal variance } \\
\text { Not equal variance }\end{array}$ & 13.599 & .000 & .020 \\
\hline $\begin{array}{l}\text { GPA } \\
\text { Equal variance } \\
\text { Not equal variance }\end{array}$ & 1.449 & .229 & .002 \\
\hline $\begin{array}{l}\text { Intellectual } \\
\text { challenge } \\
\text { Equal variance } \\
\text { Not equal variance }\end{array}$ & 2.641 & .105 & .004 \\
\hline
\end{tabular}

Table 4. Independent t-test Results

Additional mean value analysis on the seven factors reveals that females placed more importance on all of the factors except for long-term earning potential. Furthermore, the male students considered the longterm earning potential, genuine interest in the subject, and job market stability (in order) most important; whereas, female students considered the genuine interest in the subject, long-term earning potential, and job market stability as the top three factors. Table 5 explains the mean value differences with the respective standard deviation.

\begin{tabular}{|c|c|c|c|}
\hline Factors & Level & Mean & $\begin{array}{l}\text { Std. } \\
\text { Deviation }\end{array}$ \\
\hline \multirow[t]{2}{*}{ Job growth } & Male & 2.17 & .835 \\
\hline & Female & 2.17 & .946 \\
\hline \multirow[t]{2}{*}{ Job stability } & Male & 1.87 & .780 \\
\hline & Female & 1.86 & .905 \\
\hline \multirow{2}{*}{$\begin{array}{l}\text { Short-term } \\
\text { earning }\end{array}$} & Male & 2.88 & .928 \\
\hline & Female & 2.88 & 1.094 \\
\hline \multirow{2}{*}{$\begin{array}{l}\text { Long-term } \\
\text { earning }\end{array}$} & Male & 1.62 & .747 \\
\hline & Female & 1.81 & .959 \\
\hline \multirow{2}{*}{$\begin{array}{l}\text { Professional } \\
\text { image }\end{array}$} & Male & 2.58 & 1.034 \\
\hline & Female & 2.39 & 1.130 \\
\hline \multirow{2}{*}{$\begin{array}{l}\text { Social } \\
\text { image }\end{array}$} & Male & 2.94 & 1.085 \\
\hline & Female & 2.70 & 1.234 \\
\hline \multirow{2}{*}{$\begin{array}{l}\text { Amt of } \\
\text { course }\end{array}$} & Male & 3.10 & 1.056 \\
\hline & Female & 2.84 & 1.188 \\
\hline \multirow[t]{2}{*}{ Aptitude } & Male & 2.23 & .749 \\
\hline & Female & 1.98 & .961 \\
\hline \multirow[t]{2}{*}{ Interest } & Male & 1.66 & .783 \\
\hline & Female & 1.30 & .641 \\
\hline \multirow[t]{2}{*}{ GPA } & Male & 2.58 & .943 \\
\hline & Female & 2.24 & 1.070 \\
\hline \multirow{2}{*}{$\begin{array}{l}\text { Intellectual } \\
\text { challenge }\end{array}$} & Male & 2.69 & .943 \\
\hline & Female & 2.37 & 1.042 \\
\hline \multirow{2}{*}{ Technology } & Male & 2.66 & .934 \\
\hline & Female & 2.61 & 1.152 \\
\hline
\end{tabular}

Table 5. Group Statistics

(Smaller numbers represent more importance)

\section{Students' Perception of IS Major}

Using the same 12 factors, the students were asked to rate the importance of the factors based on their knowledge and perceptions of the IS major. Table 6 shows the results of the independent t-test on collegeaged respondents and high school-age respondents. Four factors - the job market growth (.004), shortterm earning potential (.032), genuine interest in the subject (.005), and use of innovative technology (.000) - showed statistically significant differences $(p<.05$ level) between the two groups. We again notice that the significance of Lavene's Test for job market growth (.006), social image (.016), aptitude (.026), and genuine interest in the subject (.040) is less than .05, so we use the "Equal Variances Not Assumed" test values for these factors (See Table 6). 


\begin{tabular}{|l|l|l|l|}
\hline \multirow{2}{*}{ Factors } & \multicolumn{2}{|l|}{$\begin{array}{l}\text { Lavene's Test } \\
\text { for Equality of } \\
\text { Variances }\end{array}$} & $\begin{array}{l}\text { t-test for } \\
\text { equality of } \\
\text { means }\end{array}$ \\
\cline { 2 - 4 } & F & Sig. & Sig.(2-tailed) \\
\hline $\begin{array}{l}\text { Job growth IS } \\
\text { Equal variance } \\
\text { Not equal variance }\end{array}$ & 7.523 & .006 & .001 \\
\hline $\begin{array}{l}\text { Short-term } \\
\text { earning IS } \\
\text { Equal variance } \\
\text { Not equal variance }\end{array}$ & 1.084 & .298 & \\
\hline $\begin{array}{l}\text { Interest IS } \\
\text { Equal variance } \\
\text { Not equal variance }\end{array}$ & 4.239 & .004 \\
\hline $\begin{array}{l}\text { Technology IS } \\
\text { Equal variance } \\
\text { Not equal variance }\end{array}$ & 4.935 & & .027 \\
\hline
\end{tabular}

Table 6. Independent t-test Results

Interestingly, mean value analysis on the four factors reveals that college students considered job growth, short-term earning potential, and use of innovative technology as more important factors for IS major than did the high school students. However, high school students considered only one factor - the genuine interest in the subject - as more important for IS major than did the college students. Also important to note, use of innovative technology, job market growth, and long-term earning potential were perceived as the three most important variables by college students; whereas, long-term earning potential, genuine interest in subject, and innovative technology were perceived as the top three variables by high school students. Table 7 explains the mean value differences with standard deviation.

\begin{tabular}{|c|c|c|c|}
\hline Factors & Level & Mean & $\begin{array}{l}\text { Std. } \\
\text { Deviation }\end{array}$ \\
\hline \multirow{2}{*}{$\begin{array}{l}\text { Job growth } \\
\text { IS }\end{array}$} & College & 2.03 & .870 \\
\hline & High school & 2.37 & .995 \\
\hline \multirow{2}{*}{$\begin{array}{l}\text { Job stability } \\
\text { IS }\end{array}$} & College & 2.24 & .995 \\
\hline & High school & 2.33 & .987 \\
\hline \multirow{2}{*}{$\begin{array}{l}\text { Short-term } \\
\text { earning IS }\end{array}$} & College & 2.63 & .967 \\
\hline & High school & 2.88 & 1.011 \\
\hline \multirow{2}{*}{$\begin{array}{l}\text { Long-term } \\
\text { earning IS }\end{array}$} & College & 2.17 & .961 \\
\hline & High school & 2.23 & .966 \\
\hline \multirow{2}{*}{$\begin{array}{l}\text { Professional } \\
\text { image IS }\end{array}$} & College & 2.64 & 1.080 \\
\hline & High school & 2.60 & 1.077 \\
\hline \multirow{2}{*}{$\begin{array}{l}\text { Social } \\
\text { image IS }\end{array}$} & College & 2.96 & 1.145 \\
\hline & High school & 2.77 & 1.185 \\
\hline \multirow{2}{*}{$\begin{array}{l}\text { Amt of } \\
\text { course IS }\end{array}$} & College & 2.71 & .956 \\
\hline & High school & 2.57 & .989 \\
\hline \multirow[t]{2}{*}{ Aptitude IS } & College & 2.53 & 1.062 \\
\hline & High school & 2.38 & 1.053 \\
\hline
\end{tabular}

\begin{tabular}{|l|l|l|l|}
\hline \multirow{2}{*}{ Interest IS } & College & $\mathbf{2 . 6 4}$ & $\mathbf{1 . 2 4 3}$ \\
\cline { 2 - 4 } & High school & $\mathbf{2 . 2 4}$ & $\mathbf{1 . 1 2 7}$ \\
\hline \multirow{2}{*}{ GPA IS } & College & 2.73 & 1.009 \\
\cline { 2 - 4 } & High school & 2.52 & .979 \\
\hline $\begin{array}{l}\text { Intellectual } \\
\text { challenge } \\
\text { IS }\end{array}$ & College & 2.45 & .941 \\
\cline { 2 - 4 } & High school & 2.57 & 1.000 \\
\hline $\begin{array}{l}\text { Technology } \\
\text { IS }\end{array}$ & College & $\mathbf{1 . 7 3}$ & $\mathbf{. 9 3 9}$ \\
\cline { 2 - 4 } & High school & $\mathbf{2 . 2 8}$ & $\mathbf{1 . 0 9 2}$ \\
\hline
\end{tabular}

Table 7. Group Statistics

(Smaller numbers represent more importance)

The differences in the male and female responses are displayed in Table 8. Seven factors - the job market growth (.033), job market stability (.032), long-term earning potential (.017), professional image of profession (.001), social image of profession (.027), amount of course work (.019), and intellectual challenge (.001) - showed statistically significant differences $(\mathrm{p}<.05$ level) between the two groups. We notice that the significance of Lavene's Test for professional image of profession (.027), social image (.011), and amount of course work (.000) is less than .05 , so we use the "Equal Variances Not Assumed" test values (the one in the bottom) for these factors

\begin{tabular}{|l|l|l|l|}
\hline \multirow{2}{*}{ Factors } & \multicolumn{2}{|l|}{$\begin{array}{l}\text { Lavene's Test } \\
\text { for Equality of } \\
\text { Variances }\end{array}$} & $\begin{array}{l}\text { t-test for } \\
\text { equality of } \\
\text { means }\end{array}$ \\
\cline { 2 - 4 } & F & Sig. & Sig.(2-tailed) \\
\hline $\begin{array}{l}\text { Job growth IS } \\
\text { Equal variance } \\
\text { Not equal variance }\end{array}$ & 1.495 & .222 & .033 \\
\hline $\begin{array}{l}\text { Job stability IS } \\
\text { Equal variance } \\
\text { Not equal variance }\end{array}$ & .709 & .400 & .039 \\
\hline $\begin{array}{l}\text { Long-term } \\
\text { earning IS }\end{array}$ & .467 & .495 & .032 \\
$\begin{array}{l}\text { Equal variance } \\
\text { Not equal variance }\end{array}$ & & & .038 \\
\hline $\begin{array}{l}\text { Professional } \\
\text { image IS }\end{array}$ & 4.921 & .027 & .017 \\
$\begin{array}{l}\text { Equal variance } \\
\text { Not equal variance }\end{array}$ & & & .019 \\
\hline $\begin{array}{l}\text { Social image IS } \\
\text { Equal variance } \\
\text { Not equal variance }\end{array}$ & 6.501 & .011 & .001 \\
\hline $\begin{array}{l}\text { Amt of course IS } \\
\text { Equal variance } \\
\text { Not equal variance }\end{array}$ & 14.168 & .000 & .001 \\
\hline $\begin{array}{l}\text { Intellectual } \\
\text { challenge IS } \\
\text { Equal variance } \\
\text { Not equal variance }\end{array}$ & 1.606 & .206 & .021 \\
\hline
\end{tabular}

Table 8. Independent t-test Results 
Further mean value analysis on the factors reveals that females considered the IS major as one with high job market growth, job market stability, long-term earnings potential, professional image of profession, social image of profession, amount of course work requirement, and intellectual challenge. The use of innovative technology, job market growth, and longterm earning potential were perceived as the most important variables by both groups. Table 9 explains the mean value differences with standard deviation.

\begin{tabular}{|c|c|c|c|}
\hline Factors & Level & Mean & $\begin{array}{l}\text { Std. } \\
\text { Deviation }\end{array}$ \\
\hline \multirow{2}{*}{$\begin{array}{l}\text { Job growth } \\
\text { IS }\end{array}$} & Male & 2.17 & .851 \\
\hline & Female & 1.98 & .981 \\
\hline \multirow{2}{*}{$\begin{array}{l}\text { Job } \\
\text { stability IS }\end{array}$} & Male & 2.34 & .944 \\
\hline & Female & 2.12 & 1.059 \\
\hline \multirow{2}{*}{$\begin{array}{l}\text { Short-term } \\
\text { earning IS }\end{array}$} & Male & 2.75 & .880 \\
\hline & Female & 2.57 & 1.122 \\
\hline \multirow{2}{*}{$\begin{array}{l}\text { Long-term } \\
\text { earning IS }\end{array}$} & Male & 2.26 & .933 \\
\hline & Female & 2.04 & .993 \\
\hline \multirow{2}{*}{$\begin{array}{l}\text { Professional } \\
\text { image IS }\end{array}$} & Male & 2.77 & 1.016 \\
\hline & Female & 2.40 & 1.142 \\
\hline \multirow{2}{*}{$\begin{array}{l}\text { Social } \\
\text { image IS }\end{array}$} & Male & 3.02 & 1.074 \\
\hline & Female & 2.76 & 1.264 \\
\hline \multirow{2}{*}{$\begin{array}{l}\text { Amt of } \\
\text { course IS }\end{array}$} & Male & 2.77 & .864 \\
\hline & Female & 2.53 & 1.096 \\
\hline \multirow[t]{2}{*}{ Aptitude IS } & Male & 2.57 & .990 \\
\hline & Female & 2.38 & 1.162 \\
\hline \multirow[t]{2}{*}{ Interest IS } & Male & 2.59 & 1.139 \\
\hline & Female & 2.52 & 1.370 \\
\hline \multirow[t]{2}{*}{ GPA IS } & Male & 2.75 & .915 \\
\hline & Female & 2.57 & 1.133 \\
\hline \multirow{2}{*}{$\begin{array}{l}\text { Intellectual } \\
\text { challenge IS }\end{array}$} & Male & 2.60 & .892 \\
\hline & Female & 2.27 & 1.019 \\
\hline \multirow{2}{*}{$\begin{array}{l}\text { Technology } \\
\text { IS }\end{array}$} & Male & 1.91 & .960 \\
\hline & Female & 1.72 & 1.044 \\
\hline
\end{tabular}

Table 9. Group statistics

(Smaller numbers represent more importance)

\section{CONCLUSIONS}

In this paper we explore the major factors influencing students' selection of a college major and students' perceptions of the Information Systems major. We found that genuine interest in the subject was the most influential factor for both high school and college students. However, male students considered long-term earning potential as the most influential factor; whereas, female students chose genuine interest in the subject. We also found that college students considered use of innovative technology as the most important variable in the IS major; whereas, high school students perceived long-term earning potential as the most important variable in the IS major. Interestingly, however, both male and female students considered use of innovative technology as the top-ranking variable in the IS major.

As detailed in the analysis section, we recognized differences between high school students and college students on three factors - amount of course work, genuine interest in the subject, and the ability to maintain high GPA. We also presented statistically significant differences between males and females on long-term earning potential, social image of profession, amount of course work, aptitude in the subject, genuine interest in the subject, GPA, and intellectual challenge of the subject. Further research will involve a factor analysis of the data by student major and age to better understand the different perceptions of the 12 factors.

\section{REFERENCES}

1. Alexander, C., Smith, L., \& Hunt, D. (2006). Inhibitors and influencers of rural students' technology-related career choices, Proceedings of the Twelfth Americas' Conference on Information Systems.

2. Cale, E.G., MaWhinney, C.H., and Callaghan, D.R. (1991). The Implications of declining enrollments in undergraduate CIS programs in the United States, Journal of Management of Information Systems, 8(1), 167-181.

3. Chabrow, E. (2006, April 24). More U.S. workers have it jobs than ever before, Information Week.

4. Denning, P.J. \& McGettrick, A. (2005). Recentering computer science, Communication of ACM, 48(11), 15-19.

5. Doyletech Corporation \& D.R. Senik \& Associates Inc. (2006, May 2). SHRC Technology Vision Conference, Summary of Results, p 2.

6. Foster, A.L. (2005, May 27). Student interest in computer science plummets, The Chronicle of Higher Education, p A31- A32.

7. Hodkinson, P. \& Sparkes, A.C. (1997). Careership: A sociological theory of career decision making, British Journal of Sociology of Education, 18(1), 29-44.

8. Hoganson, K. (2004). Computer science curricula in a global competitive environment, Journal of Computing Sciences in Colleges, 20(1), 168-177.

9. Kothuri, S. (2002). Knowledge in organizations, Available from: http://www.gse.harvard.edu/ t656_web/Spring_2002_students/kothuri_smita 
_knowledge_in_orgs.htm\#_ednl [Accessed February 2007].

10. Lenox, T.L., Woratschek, C.R., \& Davis, G.A. (2005). Exploring declining CS/IS/IT Enrollments, ISECON 2005 22nd Annual Information Systems Education Conference Proceedings.

11. Lomerson, W.L. \& Pollacia, L.F. (2006, July 18). Declining CIS enrollment: An examination of pre-college factors, Information Systems Education Journal, 4(35).

12. Mahmoud, Q.H. (2005). Revitalizing computing science education, Computer, 38(5), p 100.

13. Maple, S.A. \& Stage, F.K. (1991). Influences on the choice of math/science major by gender and ethnicity, American Educational Research Journal, 28(1), 37-60.
14. Occupational Outlook Handbook, 2006-07 Edition, U.S. Bureau of Labor Statistics, http://www.bls.gov/oco/home.htm.

15. Piccoli, G. \& Ives, B. (2005). IT dependent strategic initiatives and sustained competitive advantage: A review and synthesis of the literature, MIS Quarterly, 29(4).

16. Rajaravivarma, R. \& Surendran, K. (2005). Coping with offsource outsourcing and enhancing student retention, ISECON 2005 22nd Annual Information Systems Education Conference Proceedings.

17. Zhang, W. (2006, April 13-15). Why IS: Understanding the factors influencing undergraduate students' intention to choose is major in business schools, ACM SIGMIS-CPR '06. 